\title{
COMPARISON OF 24 HOUR URINARY PROTEIN AND SPOT URINARY PROTEIN-CREATININE RATIO IN THE ASSESSMENT OF PROTEINURIA IN PATIENTS WITH GLOMERULONEPHRITIS
}

\author{
AHMED PI ${ }^{1}$, ISLAM MN ${ }^{2}$, ALAM MB $^{3}$, BHUIYA FK ${ }^{4}$, NOMAN MU ${ }^{5}$, CHOWDHURY MN $^{6}$
}

\begin{abstract}
:
Context: Glomerulonephritis is an important cause of morbidity and mortality among all age group in Bangladesh. This cross sectional study was carried out with an aim to observe the comparison of 24 hour urinary protein and spot urinary protein-creatinine ratio in patients with glomerulonephritis in 3 group: on basis of 24 hour total protein, GFR level and serum albumin level.
\end{abstract}

Methods: A total number of 128 consecutive patients having glomerulonephritis with 18 to 70 years who came in the Nephrology Unit, Dhaka Medical College Hospital, Dhaka, during the period of January to December of 2011 were included in this study. Patients with proteinuria other than glomerulonephritis like DM, UTI and Hypertension and $<18$ years of age were excluded from the study.

Results: A significant positive correlation was found between 24 hour Urine Protein with Protein Creatinine Ratio on the patients having 24 hour Urinary protein $<0.2 \mathrm{gm}, 0.2-<1 \mathrm{gm}, 1$ 3.4 gm and 3.5-6 gm respectively. No correlation was found between $24 \mathrm{hr}$ Urine Protein with Protein Creatinine Ratio on the patients having 24 hour Urinary protein $>6 \mathrm{gm}$. A significant positive correlation was also found between 24 hour Urine Protein (gm/24 hour) with Protein Creatinine Ratio, which were in patients having GFR $<15 \mathrm{ml} / \mathrm{min} / 1.73 \mathrm{~m}^{2}$ body surface area, $15-29 \mathrm{ml} / \mathrm{min} / 1.73 \mathrm{~m}^{2}$ body surface area, $30-59 \mathrm{ml} / \mathrm{min} / 1.73 \mathrm{~m}^{2}$ body surface area, $60-89 \mathrm{ml} /$ $\mathrm{min} / 1.73 \mathrm{~m}^{2}$ body surface area and $e^{\prime 9} 90 \mathrm{ml} / \mathrm{min} / 1.73 \mathrm{~m}^{2}$ body surface area respectively. However, the result of the group having GFR $<15 \mathrm{ml} / \mathrm{min} / 1.73 \mathrm{~m}^{2}$ body surface was positively correlated but not very convincing. In this present series it was observed that a significant positive correlation was found between $24 \mathrm{hr}$ Urine Protein $(\mathrm{gm} / 24 \mathrm{hour})$ with Spot Urinary Protein Creatinine Ratio in relation to serum albumin level; $r=0.658 ;(p<0.001)$ and $r=0.707$; $(p<0.001)$ in patients having serum albumin level $>30 \mathrm{gm} / \mathrm{dl}$ and $20-30 \mathrm{gm} / \mathrm{dl}$ respectively. But because of only one sample in the group having $<20 \mathrm{gm} / \mathrm{dl}$ serum albumin, no comparison could be carried out.

Conclusion: $P / C$ ratio provided a very useful, simple and convenient method for quantitative assessment of protein and can replace 24 hour urine collection method in indoor, outpatients and in follow up clinics as it gives quick and reliable results and avoids the inconvenience and short comings associated with 24 hour urine collection.

Key Words: Glomerulonephritis, 24 hour Urinary Total Protein, Urinary Protein Creatinine Ratio.

J Dhaka Med Coll. 2014; 23(2) : 194-202.

1. Dr. Parvez Iftekhar Ahmed, Assistant Professor, Department of Nephrology, Dhaka Medical College \&Hospital, Dhaka.

2. Dr. Md. Nazrul Islam, Associate Professor, Department of Nephrology, Dhaka Medical College \& Hospital, Dhaka.

3. Dr. Md. BabrulAlam, Assistant Professor, Department of Nephrology, National Institute of Kidney Diseases and Urology (NIKDU), Dhaka.

4. Dr. Ferdous Kamal Bhuiya, Assistant Professor, Department of Nephrology, Dhaka Medical College \&Hospital, Dhaka.

5. Dr. Mesbah Uddin Noman, Consultant, Medicine, DGHS, Dhaka.

6. Prof. Md. Nizamuddin Chowdhury, Professor and Head, Department of Nephrology, Dhaka Medical College \& Hospital,Dhaka.

Correspondence: Dr. Parvez Iftekhar Ahmed, Assistant Professor, Department of Nephrology, Dhaka Medical College \& Hospital, Dhaka. 


\section{Introduction:}

Glomerulonephritis is an important cause of morbidity and mortality among all age group in the world ${ }^{1}$. Glomerulonephritis (GN) means "inflammation of the glomeruli" and although inflammation is not apparent in all varities (glomerulopathy is sometimes used to denote this), the name sticks ${ }^{1,2}$. The clinical and biochemical disturbances that accompany the glomerulopathies are direct or indirect result of few fundamental disturbances : (a) alteration of the permeselectivity of the glomerular capillary wall leading to proteinuria; (b) alteration in the filtering surface area and/or intrinsic hydraulic conductivity of the capillary wall of many or most glomeruli or loss of entire nephron, leading to reduction in GFR; (c) disturbances in the regulation of $\mathrm{NaCl}$ and water excretion leading to expansion of extracellular volume as edema and/or hypertention; (d) facilitated migration of circulating cellular elements of blood into the individual nephrons manifested as increased urinary excretion of erythrocytes, leukocytes, casts, and tubular epithelial cells ${ }^{2-4}$. To diagnose glomerulonephritis, urinary protein estimation plays the key role. Twenty-four hundred years ago, Hippocrates noted the association between "bubbles on the surface of the urine" and kidney disease ${ }^{3}$. Though 24 hour urinary protein is the gold standard test for assessment of proteinuria but it is often inaccurate, time consuming, cumbersome, inconvenient and unreliable, since it is difficult to collect a complete 24 hour urine sample accurately ${ }^{5,6}$. Moreover total urinary protein has a variation with urinary volume. To obviate these difficulties short timed urine collection have been advocated with the hypothesis that protein excretion is nearly constant throughout the day and various studies have estimated proteinuria by taking urine samples at 2 hour, 3 hour and 4 hour $^{7,8}$. These studies however were not validated. Because of problems with timed urine collection, 24 hours urinary protein excretion using single timed voided sample has been estimated. It has been reported that in the presence of stable GFR (Glomerular Filtration Rate) urinary creatinine excretion is fairly constant in a given individual, the fact serving as the principle behind the use of protein creatinine ratio in quantifying 24 hour proteinuria 9 .

Many investigators have studied the correlation between 24 hour urinary protein and proteinuria estimated from spot urinary protein - creatinine ratio in diverse group of patients such as children, diabetes, nondiabetes, SLE, pregnant female, preeclampsia and diverse renal diseases in different part of the world ${ }^{10-15}$. Keeping this in mind, and to answer the question the present study has been conducted to establish the use of spot urinary protein creatinine ratio to assess proteinuria and to substitute 24 hour urinary protein in glomerulonephritis patients in our community.

\section{Methods:}

This cross-sectional study was carried out in the Department of Nephrology, Dhaka Medical College Hospital, Dhaka, from January to December of 2011. Study population was as the patients of all type of glomerulonephritis who has been attended the Nephrology Unit, Dhaka Medical College Hospital, Dhaka. Sample was collected with convenience sampling as per inclusion and exclusion criteria. Inclusion criteria were the patients (both sexes) with glomerulonephrits in all types, Age more than 18 years. Exclusion criteria were Patients with proteinuria other than glomerulonephritis like DM,UTI and Hypertension, Patients under age of 18 years. After registration of the patient detail history has been taken and physical examination has been done. Suspected glomerulonephritis patient was at first diagnosed clinically. Then the patient was diagnosed on the basis of Urinary Heat Coagulation Test, Urinary Assay, 24 hour urinary protein Assay, Urinary Protein Creatinine Ratio and other biochemical tests. Finally the patient was diagnosed histologically. The current study duration was of 12 months and 128 patients having glomerulonephritis were included in this study. Patient who had fulfill the inclusion criteria has been enrolled in the study. Detail history, physical examination and investigation has been 
recorded in a pre designed questionnaire. After completion of collection of data, statistical analysis has been done using the SPSS version 11.5. Values has been expressed where necessary as frequency, mean, SD, or on percentage .Prior permission was taken for this study from the Ethical Review Committee of Dhaka Medical College, Dhaka, keeping compliance with Helsinki Declaration for Medical Research Involving Human Subjects 1964, all patients were informed verbally about the study design, the objective, and right for the participant to withdraw from the project at any time, for any reason, what so ever. Written consent was obtained from each subject.

\section{Results:}

In this current study it was observed that most $(31.3 \%)$ of the patients were in the age group of 31 to 40 years and the mean $\pm \mathrm{SD}$ of age was $32.94 \pm 12.66$ years ranging from 18 to 70 years. $64.8 \%$ was male and $35.2 \%$ was female. Male female ratio was $1.8: 1$, which indicates that male was predominant in this current study (fig. 1).

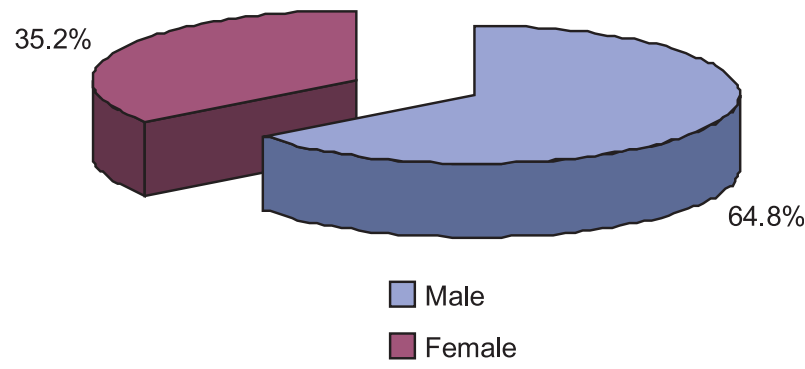

Fig.-1: Sex distribution of the study patients

It was also found that a significant positive correlation $(\mathrm{r}=0.721 ; \mathrm{p}<0.001)$ was found between $24 \mathrm{hr}$ Urine Protein (gm/24 hour) with Protein Creatinine Ratio on the patients having $24 \mathrm{hr}$ Urinary protein $<0.2 \mathrm{gm}$. However, a positive correlation $(\mathrm{r}=0.788 ; \mathrm{p}<0.001)$ was found between $24 \mathrm{hr}$ Urine Protein (gm/24 hour) with Protein Creatinine Ratio on the patients having $24 \mathrm{hr}$ Urinary protein $0.2-<1$ gm (Fig.2). In this study, it was observed that a significant positive correlation was found between $24 \mathrm{hr}$ Urine Protein (gm/24 hour) with Protein Creatinine Ratio $\mathrm{r}=0.688 ;(\mathrm{p}<0.001)$ and $\mathrm{r}=0.728 ;(\mathrm{p}<0.001)$ on the patients having 24 hr Urinary protein 1-3.4 gm and 3.5-6 gm respectively. No correlation $(\mathrm{r}=0.092 ; \mathrm{p}<0.734)$ was found between $24 \mathrm{hr}$ Urine Protein (gm/ 24 hour) with Protein Creatinine Ratio on the patients having $24 \mathrm{hr}$ Urinary protein $>6 \mathrm{gm}$.

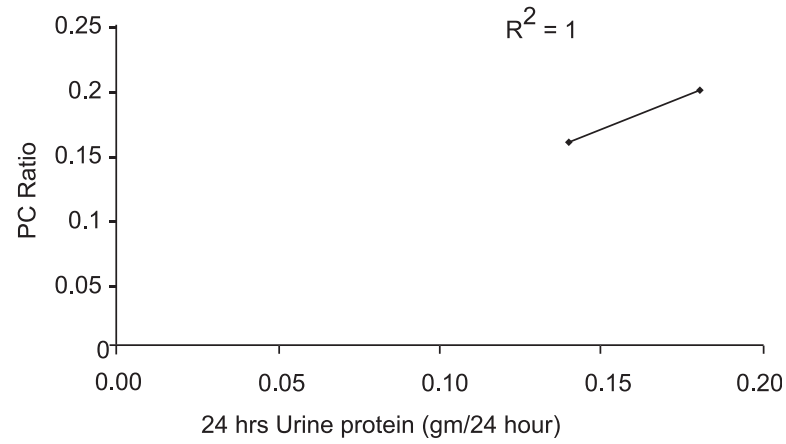

Fig. 2: Scatter diagram showing positive correlation $(r=0.721 ; p<0.001)$ between $24 \mathrm{hr}$ Urine Protein (gm/24 hour) with Protein Creatinine Ratio on the patients having $24 \mathrm{hr}$ Urinary protein: $<0.2$ $\mathrm{gm} / 24$ hour.

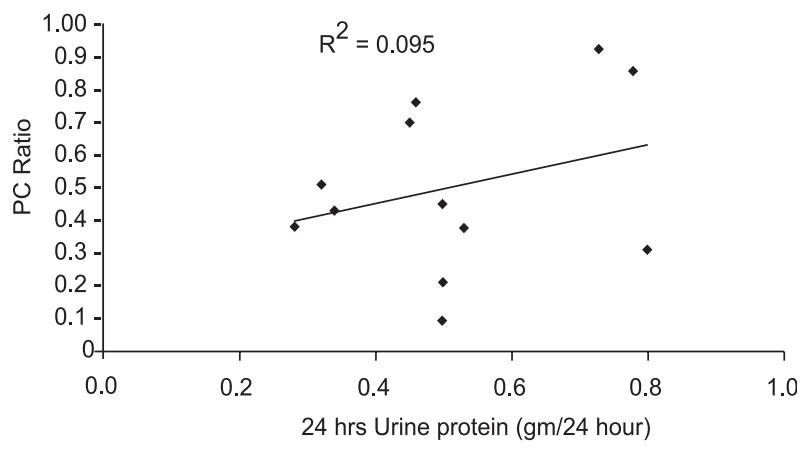

Fig.-3: Scatter diagram showing positive correlation ( $r=0.788 ; p<0.001)$ between $24 \mathrm{hr}$ Urine Protein (gm/24 hour) with Protein Creatinine Ratio on the patients having $24 \mathrm{hr}$ Urinary protein: 0.2$<1 \mathrm{gm} / 24$ hour.

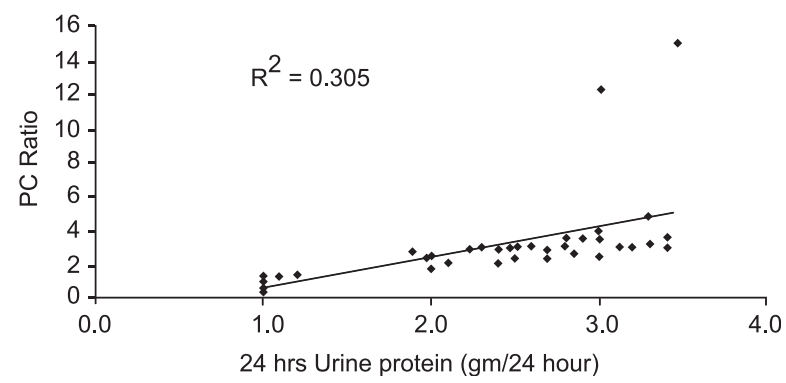

Fig.-4: Scatter diagram showing positive correlation ( $r=0.688 ; p<0.001$ ) between $24 \mathrm{hr}$ Urine Protein (gm/24 hour) with Protein Creatinine Ratio on the patients having $24 \mathrm{hr}$ Urinary protein: 1$3.4 \mathrm{gm} / 24$ hour. 


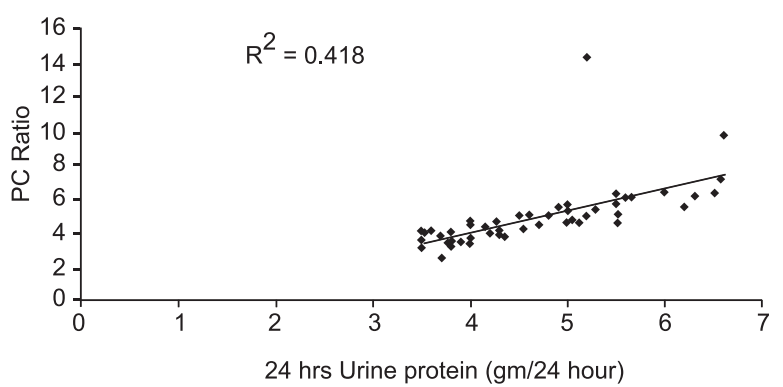

Fig.-5: Scatter diagram showing positive correlation ( $r=0.728 ; p<0.001$ ) between $24 \mathrm{hr}$ Urine Protein (gm/24 hour) with Protein Creatinine Ratio on the patients having $24 \mathrm{hr}$ Urinary protein: 3.5$6 \mathrm{gm} / 24$ hour.

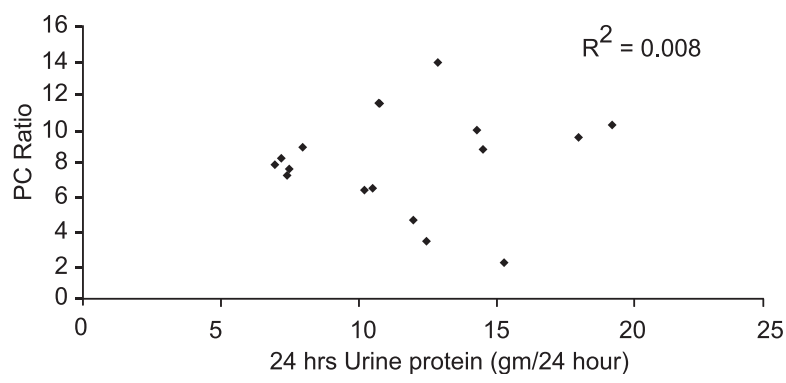

Fig.-6: Scatter diagram showing no correlation ( $r=0.092 ; p<0.734)$ between $24 \mathrm{hr}$ Urine Protein (gm/ 24 hour) with Protein Creatinine Ratio on the patients having 24 hr Urinary protein: $>6$ gm/ 24 hour.

In this current study, the patients were divided in 5 groups according to glomerular filtration rate and observed that all of the study patients had nearly equal distribution of GFR. Less than $15 \mathrm{ml} / \mathrm{min} / 1.73 \mathrm{~m}^{2}$ body surface area GFR was observed in $29(22.7 \%)$ of the study patients. Same was observed in 15 to $29 \mathrm{ml} / \mathrm{min} / 1.73 \mathrm{~m}^{2}$ body surface area GFR patients. However, $28(21.3 \%)$ had $30-89 \mathrm{ml} / \mathrm{min} / 1.73 \mathrm{~m}^{2}$ body surface area GFR, 23(18.0\%) had 60-89 ml/ min $/ 1.73 \mathrm{~m}^{2}$ body surface area GFR and $19(14.8 \%)$ had $^{3} 90 \mathrm{ml} / \mathrm{min} / 1.73 \mathrm{~m}^{2}$ body surface area GFR.

In this study, it was observed that a significant positive correlation was found between $24 \mathrm{hr}$ Urine Protein ( $\mathrm{gm} / 24$ hour) with Protein Creatinine Ratio, which were $\mathrm{r}=0.535$, $(p<0.003) ; \quad r=0.785,(p<0.001) ; \quad r=0.987$, $(\mathrm{p}<0.001) ; \quad \mathrm{r}=0.734,(\mathrm{p}<0.001) ; \quad \mathrm{r}=0.777$, $(\mathrm{p}<0.001)$ in patients having GFR $<15 \mathrm{ml} / \mathrm{min} /$ $1.73 \mathrm{~m}^{2}$ body surface area, $15-29 \mathrm{ml} / \mathrm{min} /$ $1.73 \mathrm{~m}^{2}$ body surface area, $30-59 \mathrm{ml} / \mathrm{min} /$
$1.73 \mathrm{~m}^{2}$ body surface area, $60-89 \mathrm{ml} / \mathrm{min} /$ $1.73 \mathrm{~m}^{2}$ body surface area and e"90 $\mathrm{ml} / \mathrm{min} /$ $1.73 \mathrm{~m}^{2}$ body surface area respectively. However the result of the group having GFR $<15 \mathrm{ml} / \mathrm{min} /$ $1.73 \mathrm{~m}^{2}$ body surface waspositively correlated but not very convincing $(\mathrm{r}=0.535 ; \mathrm{p}<0.003)$.

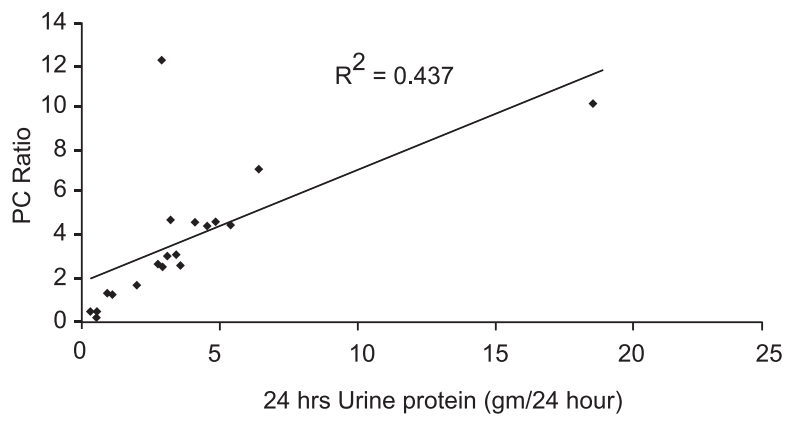

Fig. 7: Scatter diagram showing positive correlation ( $r=0.777 ; p<0.001)$ between 24 hr Urine Protein (gm/24 hour) with Protein Creatinine Ratio on the patients having GFR: e"90 ml/min/1.73m2 body surface area.

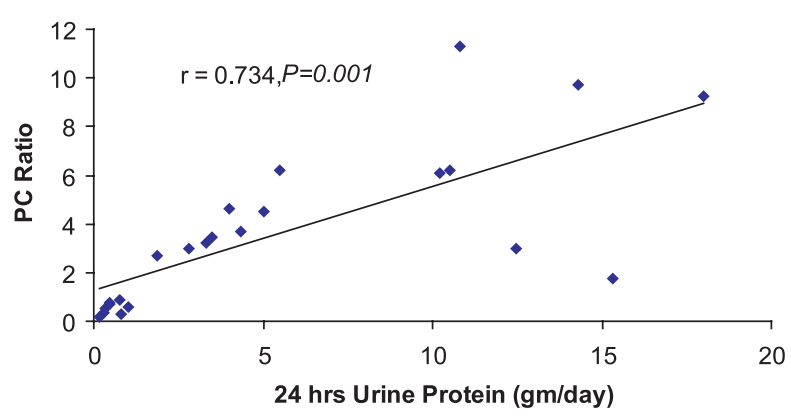

Fig. 8: Scatter diagram showing positive correlation ( $r=0.734 ; p<0.001$ ) between $24 \mathrm{hr}$ Urine Protein (gm/24 hour) with Protein Creatinine Ratio on the patients having GFR: $60-89 \mathrm{ml} / \mathrm{min} /$ $1.73 \mathrm{~m} 2$ body surface area.

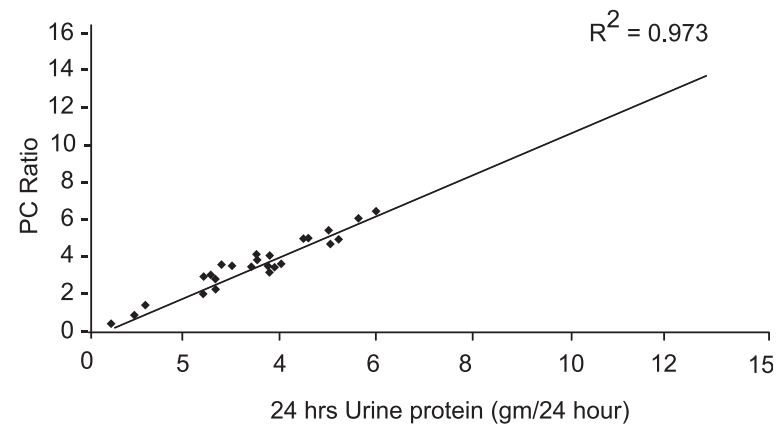

Fig. 9: Scatter diagram showing positive correlation ( $r=0.987 ; p<0.001$ ) between 24 hr Urine Protein (gm/24 hour) with Protein Creatinine Ratio on the patients having GFR:30-59 $\mathrm{ml} / \mathrm{min} /$ $1.73 \mathrm{~m} 2$ body surface area. 


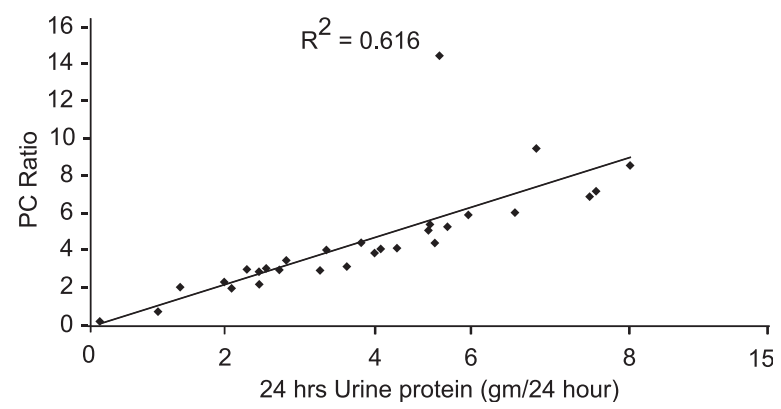

Fig. 10: Scatter diagram below showing positive correlation ( $r=0.785 ; p<0.001$ ) between $24 \mathrm{hr}$ Urine Protein (gm/24 hour) with Protein Creatinine Ratio on the patients having GFR: $15-29 \mathrm{ml} / \mathrm{min} /$ $1.73 \mathrm{~m} 2$ body surface area.

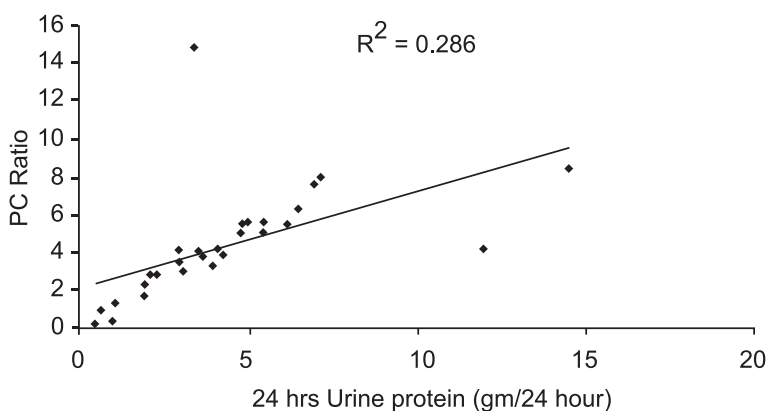

Fig. 11: Scatter diagram showing positive correlation ( $r=0.535$; $p<0.003$ ) between $24 \mathrm{hr}$ Urine Protein (gm/24 hour) with Protein Creatinine Ratio on the patients having GFR: $<15 \mathrm{ml} / \mathrm{min} / 1.73 \mathrm{~m} 2$ body surface area.

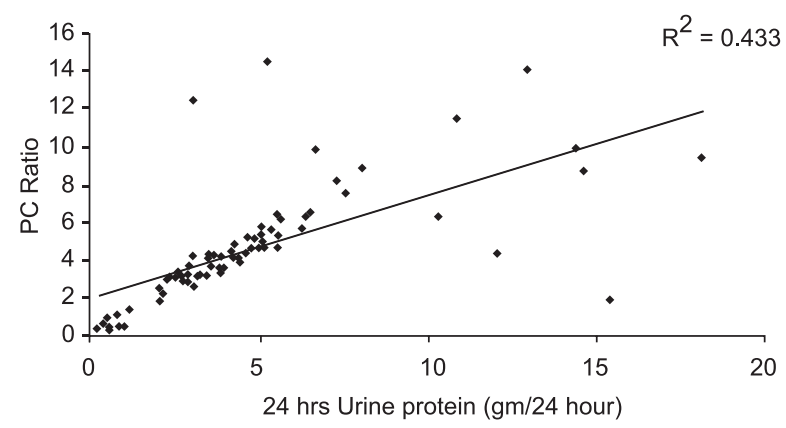

Fig. 12: Scatter diagram showing positive correlation ( $r=0.658 ; p<0.001$ ) between $24 \mathrm{hr}$ Urine Protein (gm/24 hour) with Protein Creatinine Ratio on the patients having Serum albumin level: $>30 \mathrm{gm} / \mathrm{dl}$.

In this present series it was observed that a significant positive correlation was found between 24 hr Urine Protein (gm/24 hour) with
Spot Urinary Protein Creatinine Ratio in relation to Serum Albumin level; $r=0.658$; $(\mathrm{p}<0.001)$ and $\mathrm{r}=0.707 ;(\mathrm{p}<0.001)$ in patients having Serum albumin level $>30 \mathrm{gm} / \mathrm{dl}$ and $20-$ $30 \mathrm{gm} / \mathrm{dl}$ respectively. But because of only one sample in the group having $<20 \mathrm{gm} / \mathrm{dl}$ Serum Albumin, no comparison could be carried out.

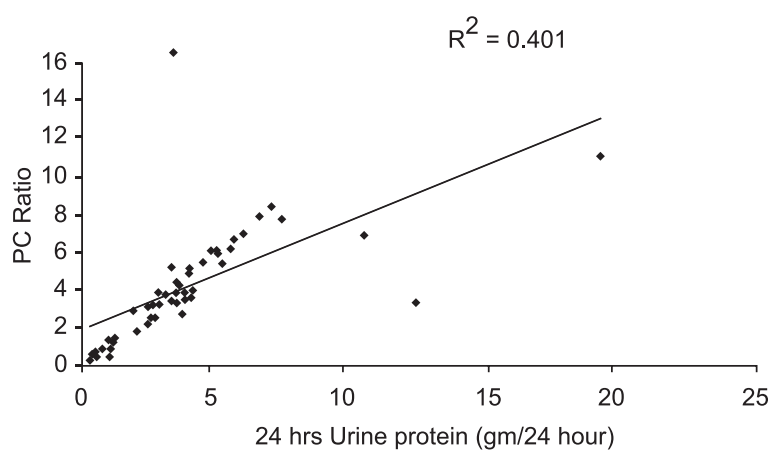

Fig. 13: Scatter diagram showing positive correlation ( $r=0.707 ; p<0.001$ ) between $24 \mathrm{hr}$ Urine Protein (gm/24 hour) with Protein Creatinine Ratio on the patients having Serum albumin level: 20$30 \mathrm{gm} / \mathrm{dl}$.

\section{Discussion:}

In this current study it was observed that most $(31.3 \%)$ of the patients were in the age group of 31 to 40 years and the mean \pm SD of age was $32.94 \pm 12.66$ years ranging from 18 to 70 years. Almost similar age range observed by Garg et al., where they found age ranged between 1470 years $^{16}$. Antunes, Veronese and Morales found the mean $\pm \mathrm{SD}$ age was $38 \pm 17$ years ${ }^{17}$. Shahbazian\& Hosseini-Asl and Khan et al. found the mean age was $26.5 \pm 3.6$ years (ranging from 17 to 36 years) and $25.6 \pm 11.7$ years (ranging from 5 to 60 years) respectively, which are lesser with the current study ${ }^{18,19}$. On the other hand, othershave observed higher mean age in their study patients, which may be due to increased life expectancy in their study patients ${ }^{20-23}$.

In this current study it was observed that $64.8 \%$ was male and $35.2 \%$ was female. Male female ratio was $1.8: 1$, which indicates that male was predominant in this current study. Similarly, some researchers showed male predominant in their study patients ${ }^{17,21,22,24}$, while others showed female predomonence 16,23 . 
In this present series it was observed that the mean \pm SD of $24 \mathrm{hr}$ Urinary Protein were $4.33 \pm 3.48 \mathrm{gm}$, ranging from 0.14 to $19.12 \mathrm{gm}$. Garg et al. showed the mean of $24 \mathrm{hr}$ urinary protein estimated by $24 \mathrm{hr}$ collection method was $3.94 \pm 1.93 \mathrm{gm}$ in patients with s. creatinine 1.5 to $4.0 \% \mathrm{mg} \%$ and $\mathrm{Kim}$ et al. found the mean \pm SD of $24 \mathrm{hr}$ urinary protein $1.31 \pm 1.69$ $\mathrm{gm}^{16,22}$.

In this current series it was observed that the mean \pm SDof $\mathrm{P} / \mathrm{C}$ ratio were $4.11 \pm 2.88$ ranging from 0.09 to 14.9 . Similar results showed in a study which is closely resembled with the current study ${ }^{17}$. On the other hand, Shahbazian \& Hosseini-Aslfound the mean of $\mathrm{P} / \mathrm{C}$ ratio was $1.84 \pm 0.91$ with range from 0.38 to $3.60^{18}$.

In this study it was observed that the mean $\pm \mathrm{SD}$ of Serum Creatinine were $3.46 \pm 2.85 \mathrm{mg} / \mathrm{dl}$ ranging from 0.5 to $12.5 \mathrm{mg} / \mathrm{dl}$. Almost similar Serum Creatinine range obtained by Garg et al. where the serum creatinine range belonged to 0.1 to $8.9 \mathrm{mg} / \mathrm{dl}^{16}$, while Shahbazian \& Hosseini-Aslshowed the median serum creatinine concentration was $0.52 \mathrm{mg} / \mathrm{dl}^{18}$ and Antunes, Veronese \& Moralesfound the mean \pm SD of Serum Creatinine $1.4 \pm 0.7 \mathrm{mg} /$ $\mathrm{d}^{17}$.

In a study, Leung et al. showed a strong significant $(\mathrm{p}<0.001)$ correlation $(\mathrm{r}=0.91)$ between spot urine $\mathrm{P} / \mathrm{C}$ ratio with 24 hour urine protein ${ }^{20}$. However, wider deviation from the line of identity was noticed in higher protein excretion levels. Using the BlandAltman plot, the limits of agreement between spot urine $\mathrm{P} / \mathrm{C}$ ratio and 24 hour urine protein were wider at higher levels of protein excretion. Protein excretion $<2.0 \mathrm{gm} / 24$ hour, the limits of agreement of spot urine $\mathrm{P} / \mathrm{C}$ ratio and 24 hour urine protein were +0.92 and $-0.86 \mathrm{gm} /$ 24 hour. With protein excretion $<1.5 \mathrm{gm} / 24$ hour, the limits of agreement were +0.87 and $0.80 \mathrm{gm} / 24$ hour. The urine $\mathrm{P} / \mathrm{C}$ ratio discriminant values of $0.37,0.45,0.7$ and 1.84 $\mathrm{mg} / \mathrm{mg}$ reliably predicted 24 hour urine protein ${ }^{3} 0.3,0.5,1.0$ and $3.5 \mathrm{gm}$, respectively.

Antunes, Veronese \& Moralesfound a significant correlation between P24 and the P/ $\mathrm{C}$ ratio during the 6 -month period $(P<0.001$ in all time points $)^{17}$. Mean differences between P24 and P/Cratio at baseline and from the first to the sixth month were $2.00,1.88,1.22,1.07$, $0.65,0.34$ and 0.57 respectively. In spite of the lower agreement between P24 and the P/C ratio for higher levels of proteinuria, they found substantial Kappa values for categories of proteinuria in all periods. ROC considering the cut-off levels of $0.20 \mathrm{~g}$ and $3.5 \mathrm{~g}$ for P24 showed that the $\mathrm{P} / \mathrm{C}$ ratio had a very good accuracy, with areas under the curve of 0.99 (95\% CI: 0.97-1.00) and 0.99 (95\% CI: 0.99-1.00), respectively. Their study findings support the current study.

Wahbeh, Ewais \& Elsharifconducted a study on sixty-eight patients and the cutoff values for spot urine protein-to-creatinine ratio in predicting 24-hour protein "threshold" excretion of $0.5,1.0$ and $3.5 \mathrm{~g} / 24$ hour were determined using receiver operating characteristic curves $^{25}$. A very good correlation $(r=0.832$, $\mathrm{P}<0.0001$ ) was found between spot urine protein-to-creatinine ratio and 24-hour urine protein excretion. Bland-Altman plot showed the two tests had reasonable limits of agreement at low level of protein excretion but the limits became wider as the protein excretion increased. For protein excretion $<2.0$ $\mathrm{g} /$ day, the limits of agreement of spot urine (PCR) and (UP) were +1.48 and $-1.2 \mathrm{~g} /$ day. The spot urine protein-to-creatinine ratios of 0.72 (sensitivity 0.97; specificity 1.0), 1.2 (0.97; 0.89) and $3.23(1.0 ; 0.86) \mathrm{mg} / \mathrm{mg}$ reliably predicted 24-hour urine total protein equivalent "thresholds" of $0.5,1.0$ and $3.5 \mathrm{~g} /$ day, respectively. They conclude that the proteinto-creatinine ratio in spot urine specimens is an accurate, convenient, and reliable method to estimate the protein excretion in urine. However, the protein-to-creatinine ratio will likely be within clinically acceptable limits only when proteinuria is at reasonably low levels. This study also supports the current study.

Shahbazian \& Hosseini-Asl showed a urine P/ $\mathrm{C}$ ratio of 0.20 corresponded with a protein excretion rate of $0.30 \mathrm{gm} / 24$ hour, which are characterized by excellent accuracy, where the investigators found a strong correlation $(\mathrm{r}=$ 0.84 ) between the spot $\mathrm{P} / \mathrm{C}$ ratio with the 24 hour urine protein ${ }^{18}$. However, using the spot 
$\mathrm{P} / \mathrm{C}$ ratio of 0.20 as a correlate to the critical value of $0.30 \mathrm{gm}$ of protein over 24 hour would result in the failure to identify significant proteinuria in approximately $8.8 \%$ of affected patients. Most previous studies done by Rodriguez-Thompson, Lieberman, Neithardt, Dooley \& Borensztajn, Saudan et al. and Robert et al. mentioned that the correlation coefficients ranging between 0.80 and 0.97 , which support the current study ${ }^{26-29}$.

However, the result of the group having GFR $<15 \mathrm{ml} / \mathrm{min} / 1.73 \mathrm{~m}^{2}$ body surface was positively correlated but not very convincing ( $r=0.535$; $\mathrm{p}<0.003$ ). Similarly, Ali, et al., (2008) showed significant positive correlation between $24 \mathrm{hr}$ Urine Protein with Protein Creatinine Ratio in 5 groups according to glomerular filtration rate, which were $\mathrm{r}=0.96, \mathrm{r}=0.81, \mathrm{r}=0.94$, $\mathrm{r}=0.82$, and $\mathrm{r}=0.80$ in $\mathrm{GFR}>90 \mathrm{ml} / \mathrm{min} / 1.73 \mathrm{~m}^{2}$ body surface area, $60-89 \mathrm{ml} / \mathrm{min} / 1.73 \mathrm{~m}^{2}$ body surface area, $30-59 \mathrm{ml} / \mathrm{min} / 1.73 \mathrm{~m}^{2}$ body surface area, $15-29 \mathrm{ml} / \mathrm{min} / 1.73 \mathrm{~m}^{2}$ body surface area and $<15 \mathrm{ml} / \mathrm{min} / 1.73 \mathrm{~m}^{2}$ body surface area respectively, which is closely resembled with the current study. He also found that in $<15 \mathrm{ml} / \mathrm{min} / 1.73 \mathrm{~m}^{2}$ body surface area GFR, correlation between $24 \mathrm{hr}$ protein and PCR was not very convening. In another study, Garg, et al. showed a significant $(\mathrm{p}<0.001)$ strong correlation $\mathrm{r}=0.889$ in group I (S. creatinine $<1.5 \mathrm{mg} \%$ ) patients between the two methods. Similar results was obtained in group II (S. creatinine 1.5-4.0 mg\%) and group III (severely impaired renal functions S.creatinine $>4.0$ $\mathrm{mg} \%$ ) were $\mathrm{r}=0.788$ and $\mathrm{r}=0.375$ respectively, which support the current study ${ }^{16}$.

In this present series it was observed that the mean $\pm \mathrm{SD}$ of $\mathrm{P} / \mathrm{C}$ Ratio was $0.38 \pm 0.0$ in patient with $<20 \mathrm{gm} / \mathrm{dl}$ Serum Albumin, that was only one sample. However, mean \pm SD of $\mathrm{P} / \mathrm{C}$ Ratio were $3.76 \pm 2.63$ ranging from 0.38 to 14.9 in patients with $20-30 \mathrm{mg} / \mathrm{dl}$ Serum Albumin. Besides, patients with $>30 \mathrm{mg} / \mathrm{dl}$ Serum Albumin had mean \pm SD of P/C Ratio 4.41 \pm 3.02 ranging from 0.09 to 14.25 .

In this present series it was observed that a significant positive correlation was found between 24 hr Urine Protein (gm/24 hour) with Spot Urinary Protein Creatinine Ratio in relation to serum albumin level; $\mathrm{r}=0.658$; $(\mathrm{p}<0.001)$ and $\mathrm{r}=0.707 ;(\mathrm{p}<0.001)$ in patients having serum albumin level $>30 \mathrm{gm} / \mathrm{dl}$ and $20-$ $30 \mathrm{gm} / \mathrm{dl}$ respectively. However, because of only one sample in the group having $<20 \mathrm{gm} /$ dl Serum Albumin, no comparison could be carried out.

Garg et al. mentioned the possible reason for the poor correlation in patients with advanced renal failure due to decreased GFR ${ }^{16}$. The results of their study are in the agreement with previous studies undertaken by Shaw, Risdon \& Lewis-Jacksonsuggested that correlation between two methods of estimation depends upon the GFR and is independent of sex, age and weight of patient ${ }^{30}$. Rodby et al. mentioned that patients with type 1 diabetes and nephropathy, the $\mathrm{P} / \mathrm{C}$ ratio of a random urine specimen may be used to estimate a range of 24 UP excretion ${ }^{31}$. The reliability of predictions is best when used in patients with lower levels of proteinuria, becoming less accurate in the nephrotic range and higher. The authors recommend caution in applying overconfidence to the values obtained with this technique and cannot recommend using this technique in following trends of proteinuria, or in following a patient's response to therapy.

The correlation between the spot $\mathrm{P} / \mathrm{C}$ ratio with the 24-hour urine protein in the present study were strengthened by similar observations also made by some researchers in their studies ${ }^{21}$, $24,25,32,33$. All these investigators observed significant correlation between the spot $\mathrm{P} / \mathrm{C}$ ratio with the 24-hour urine protein. Thus, $\mathrm{P} /$ $\mathrm{C}$ ratio provided a very useful, simple and convenient method for quantitative assessment of protein and can replace $24 \mathrm{hr}$ urine collection method in indoor, outpatients and in follow up clinics as it gives quick and reliable results and avoids the inconvenience and shortcomings associated with $24 \mathrm{hr}$ urine collection. However, a significant positive correlation was $(\mathrm{r}=0.668 ; \mathrm{p}<0.001)$ between Protein Creatinine Ratio with Urinary Heat Coagulation Test and ( $\mathrm{r}=0.650 ; 0.001)$ between $24 \mathrm{hr}$ Urinary Protein with Urinary Heat Coagulation Test. 


\section{Conclusion:}

A significant positive correlation was observed between 24 hr Urine Protein (gm/24 hour) with Protein Creatinine Ratio in different levels of glomerular filtration rate, though the result of the group having GFR $<15 \mathrm{ml} / \mathrm{min} / 1.73 \mathrm{~m}^{2}$ body surface was not very convincing. A significant positive correlation was observed between 24 hr Urine Protein (gm/24 hour) with Protein Creatinine Ratio in different level of serum albumin. Also a significant positive correlation was observd between $24 \mathrm{hr}$ Urine Protein (gm/ 24 hour) with Protein Creatinine Ratio in different level of proteinuria, but there is a no correlation in higher level of proteinuria. Therefore, $\mathrm{P} / \mathrm{C}$ ratio as an accurate test to define critical levels of proteinuria and the use of the $\mathrm{P} / \mathrm{C}$ ratio in the clinical setting by its simplicity and low cost and it can be used as a substitute of $24 \mathrm{hr}$ urinary protein estimation.

\section{References:}

1. Goddard J, Turner AN, Stewart LH. Kidney and Urinary Tract Disease. In :ColledgeNR, Walker BR, Ralston SH. Davidson's Principle and Practice of Medicine. $21^{\text {st }}$ ed. London: Churchill Livingstone; 2010: p.500.

2. Glassock RJ. Proteinuria. In: Massry SG, GlassockRJ. Massry \&Glassock's Textbook of Nephrology. $4^{\text {th }}$ ed. New York: Lippincoot Williams \& Wilkins; 2001: p.545-9.

3. Beetham R, Cattell WR. Proteinuria: pathophysiology, significance and recommendation for measurement in clinical practice. Ann ClinBiochem 1993; 30(5):425-34.

4. World Health Organization Blood: Safety and Laboratory Technology Regional Office for SouthEast Asia, World Health House, Indraprastha Estate, Mahatama Gandhi Marg, New Delhi 110 002, India. Available at: <http:// www.searo.who.int/en/Section 10/Section 17/ Section493.htm> [Accessed 21 October, 2010].

5. Carroll MF, Temte JL. Proteinuria in Adults: A Diagnostic Approach. Am AcadFamPhys 2000; 62(6):1333-40.

6. NKF/KDOQI,2000. Available at: <http:// www.kidney.org / professionals / kdoqi / guidelines_ckd/p5_lab_g5.htm> [Accessed 22 October, 2010].

7. Eknoyan G, Hostetter T, Bakris GL, Hebert L, Levey AS, Parving HH. Proteinuria and other markers of chronic kidney disease: a position statement of the National Kidney Foundation (NKF) and National Institute of Diabetes and Digestive and Kidney Diseases (NIDDK). Am J Kidney Dis 2003; 42:617-22.

8. Sharma BK, Jain PK, Jindal SK. Urinary protein excretion in normal Indian subject. Ind $\mathrm{J}$ Med Res 1981; 74:286.

9. Garg S, Gupta AK, Rohtgi A, Sharma SK.Evaluation of Random Urine Sample ProteinCretinine Ratio as an Index of Quantitative Proteinuria. Publication From Dept. of Medicine of Lady Hardinge Medical College \& Smt. Sucheta Kriuplani Hospital \& Appolo Hospitals. New Delhi: JK Science;2004; 6(3):134-7.

10. Vestergaard P, Leverett R. Constancy of urinary creatinine excretion, J Lab Clin Med 1958; 51:211-5.

11. Ginsberg JM, Chang BS, Matarese RA, Garella S. Use of Single Voided Urine Samples to Estimate Quantitative Proteinuria. New Engl J Med 1983; 309:1543-6.

12. SessomsS, Mehta K, Kovarsky J. Quantification of o proteinuria in systemic lupus erythematosus by use random, spot urine collection. Arthritis Rheumatism 1983; 26:918-20.

13. Rathi DP, Bansal RC, Malhotra KK. Spot urine test for quantitative estimation of proteinuria. $\mathrm{J}$ AssocPhysInd 1985; 33:781.

14. Parag KB, Seedat YK. PC ratio- A semiquantitativ assessment of 24 hour protein excretion. SamtDeel 1988; 69:42-4.

15. Schwab SJ, Christensen RL, Dougherty K, Klahr S. Quantitation of proteinuria by the use of proteinto-creatinine ratios in single urine samples. Arch Intern Med 1987; 147:943-4.

16. Kristal B, Shasha SM, Labin L, Cohen A. Estimation of quantitative proteinuria by using the protein creatinine ratio in random urine samples. Am J Nephrol 1988; 8:198-203.

17. Antunes VVH, Veronese FJV, Moralesb JV. Diagnostic accuracy of the protein/creatinine ratio in urine samplesto estimate $24-\mathrm{h}$ proteinuria in patients with primary glomerulopathies: a longitudinal study. NephrolDialys Transplant 2008; 23:2242-6.

18. Shahbazian N, Hosseini-AslF. A Comparison of Spot Urine Protein-Creatinine Ratio With 24-hour Urine Protein Excretion in Women With Preeclampsia. Iranian J Kidney Dis2008; 2(3): 127-131.

19. Khan DA, Ahmad TM, Qureshi AH, Halim A, Ahmad M, Afzal S. Assessment of Proteinuria by using Protein: Creatinine Index in Random Urine Sample. J Pak Med Assoc 2005; 55:428-31. 
20. Leung YY, Szeto CC, Tam LS, et al. Urine protein-to creatinine ratio in an untimed urine collection is a reliable measure of proteinuria in lupus nephritis. Oxford J Rheumatol2007; 46(4):649-52.

21. Kim SJ, Cho AS, Lee JH, et al. Comparison of the Urine Protein to Creatinine Ratio with 24Hour Urinary Protein Amounts in Patients with Kidney Transplants. Korean J Med 2011; 81(1):828.

22. Ali A, Asif N, Yaqub S, Kashif W, Merchant D, Yazdani I. Spot Urine Protein: Creatinine Ratio versus 24 Hour Urine Protein at Various Levels of GFR patients referred to a Tertiary Care Hospital of Pakistan. J Pak Med Assoc 2008; 58:476-8.

23. Sadjadi SA, JaipaulN. Correlation of random urine protein creatinine $(\mathrm{P}-\mathrm{C})$ ratio with 24 -hour urine protein and $\mathrm{P}-\mathrm{C}$ ratio, based on physical activity: a pilot study. Therapeutics and Clinical Risk Management 2010; 6:351-7.

24. Yadav BK, Adhikari S, Gyawali P, Shrestha R, Poudel B, Khanal M.Use of Protein: creatinine ratio in a random spot urine sample for predicting significant proteinuria in diabetes mellitus. Nepal Med Coll J2010; 12(2):100-5.

25. Wahbeh AM, Ewais MH, Elsharif ME. Comparison of 24-hour urinary protein and protein-tocreatinine ratio in the assessment of proteinuria. Saudi J Kidney Dis Transplant 2009; 20(3): 443-447.

26. Rodriguez-Thompson D, Lieberman ES. Use of a random urinary protein-to-creatinine ratio for the diagnosis of significant proteinuria during pregnancy. Am J ObstetGynecol 2001; 185: 808-11.

27. Neithardt AB, Dooley SL, BorensztajnJ. Prediction of 24 hour protein excretion in pregnancy with a single voided urine protein-to-creatinine ratio. Am J Obstet Gynecol 2002; 186:883-6.

28. Saudan PJ, Brown MA, Farrell T, Shaw L. Improved methods of assessing proteinuria in hypertensive pregnancy. Br J Obstet Gynaecol 1997; 104:1159-64.

29. Robert M, Sepandj F, Liston RM, Dooley KC. Random protein-creatinine ratio for the quantitation of proteinuria in pregnancy. ObstetGynecol 1997; 90:893-5.

30. Shaw AB, Risdon P, Lewis-Jackson JD. Protein creatinine index and albustix in assessment of proteinuria.BMJ 1983; 287:929-32.

31. Rodby RA, Rohde RD,ZeevS, Pohl MA, Bain RP, Lewis EJ. The urine protein to creatinine ratio as a predictor of 24-hour urine protein excretion in type 1 diabetic patients with nephropathy. Am J Kidney Dis 1995; 26(6):904-9.

32. Price CP, Ronald GN, James CB.Use of Protein: Creatinine Ratio Measurements on Random Urine Samples for Prediction of Significant Proteinuria: A Systematic Review. Am Assoc Clin hem 2005; 51:1577-86.

33. Agarwal I, Kirubakaran C, Markandeyulu , Selvakumar. Quantitation of Proteinuria by Spot Urine Sampling. Indian J ClinBiochem 2004; $19(2): 45-7$. 